\title{
(-)-Epigallocatechin-3-gallate blocks nicotine-induced matrix metalloproteinase-9 expression and invasiveness via suppression of NF-кB and AP-1 in endothelial cells
}

\author{
PHAM NGOC KHOI, JUNG SUN PARK, JIN HEE KIM, YONG XIA, \\ NAM HO KIM, KYUNG KEUN KIM and YOUNG DO JUNG
}

Research Institute of Medical Sciences, Chonnam National University Medical School, Gwangju 501-190, Republic of Korea

Received May 2, 2013; Accepted June 17, 2013

DOI: 10.3892/ijo.2013.2006

\begin{abstract}
Cigarette smoke, specifically the nicotine contained within, has been shown to correlate closely with cell invasion and strategies to downregulate their expression may ultimately be of clinical utility. Matrix metalloproteinase- 9 (MMP-9) is critically involved in the cell invasion and metastasis processes. Since nicotine plays a crucial role in the regulation of MMP-9 expression, the investigation of plant-derived compounds capable of modulating nicotineinduced signaling is an issue of concern. In this study, the effects of (-)-epigallocatechin-3-gallate (EGCG), a major green tea catechin, on nicotine-induced cell invasion and MMP-9 activity in ECV304 human endothelial cells were examined. EGCG treatment was found to reduce the MMP-9 expression and transcriptional activity in a dose-dependent manner. EGCG inhibited nicotine-activated production of reactive oxygen species (ROS), which are known as important signaling molecules to activate MMP-9. To further study the mechanisms for the EGCG-mediated regulation of MMP-9, the transcription factors NF- $\mathrm{KB}$ and AP-1 activities were examined. EGCG suppressed the nicotine-induced NF- $\kappa \mathrm{B}$ and AP-1 activation. Studies with expression vectors encoding mutated NF- $\mathrm{kB}$ signaling molecules and AP-1 decoy confirmed that NF- $\mathrm{kB}$ and AP-1 were essential for the nicotine-stimulated MMP-9 expression. EGCG also abrogated the nicotine-induced activation of AP-1 subunits c-fos and c-jun. The above studies demonstrate that EGCG may exert at least part of its anti-invasive effect in ECV304 human endothelial cells by controlling MMP-9 expression through the suppression of ROS, NF- $\mathrm{kB}$ and AP-1.
\end{abstract}

Correspondence to: Dr Young Do Jung, Department of Biochemistry, Chonnam National University Medical School, 5 Hakdong, Gwangju 501-190, Republic of Korea

E-mail: ydjung@chonnam.ac.kr

Key words: EGCG, nicotine, MMP-9, ROS, NF-кB, AP-1, cell invasion

\section{Introduction}

Chemical-analytical studies have led to the identification of $\sim 3,000$ compounds in tobacco. These include carcinogens in processed tobacco as well as tumor initiators, tumor promoters, cocarcinogens and organ-specific carcinogens in tobacco smoke. Some of these compounds such as 4-(methylnitro samino)-1-(3-pyridyl)-1-butanone and N'-nitrosonornicotine are nicotine derivatives and highly carcinogenic (1). Nicotine is the major addictive component of tobacco smoke. Although nicotine is generally thought to have limited ability to initiate cancer, it can induce cell proliferation and angiogenesis in a variety of systems. A recent finding suggested that nicotine may at least be partially involved in the initiation, promotion and even progression of tumors (2). However, the effect of nicotine on cancer cell invasion is still not clear.

Epidemiological studies have shown that the consumption of green tea decreases the risk of developing human cancers (3). The anti-carcinogenic and anti-proliferative effects of green tea have been attributed to the biological activities of its polyphenol components. Green tea extract contains (-)-epicatechin (EC), (-)-epicatechin gallate (ECG), (-)-epigallocatechin (EGC) and (-)-epigallocatechin-3-gallate (EGCG) (4). EGCG, the most abundant polyphenol in green tea, has been considered to be the major chemopreventive constituent of tea and has been the focus of a great deal of attention. EGCG inhibits proliferation and induces apoptosis of tumor cells $(5,6)$. The exact mechanisms underlying the anticarcinogenic activity of tea are not well defined and warrant further study. In addition to having a cancer chemopreventive activity, polyphenols have been shown to inhibit tumor invasion, which is a crucial step for the metastasis of all solid tumors. It was proposed recently that the anticancer activity of EGCG is associated with the inhibition of invasion by inhibiting the matrix metalloproteinases (MMPs) (7), activity of urokinase (8) and removal of oxygen radicals (9), all of which play key roles in cancer invasion and metastasis. Previously, we reported that mice treated with EGCG resulted in marked inhibition of vascularity and proliferation of human colon cancer xenografts model (10).

Cancer invasion and metastasis are multistep processes and require the coordinated action of cell-secreted proteolytic enzymes and their inhibitors. Matrix metalloproteinases 
(MMPs) are a family of zinc containing enzymes which are involved in the degradation of different components of the extracellular matrix and there is considerable evidence indicating that individual MMPs have important roles in tumor invasion and spread (11). Of the MMPs, MMP-9 (gelatinase B) cleaves matrix substrates including gelatin and collagen types IV, V and VII (12). In addition, several extracellular stimuli have been reported to regulate the activities of MMPs in various cell types $(13,14)$. In cancer, it has recently been reported that MMP-9 is related to the initial step of cancer cell invasion and that the plasma level of MMP-9 in patients correlates with the tumor metastatic potential. As reported in related studies $(15,16)$, it is clear that MMP-mediated degradation of extracellular matrix is a hallmark in several pathologic conditions such as arthritis, inflammation, cancer, angiogenesis, cardiovascular, pulmonary, ocular, gastrointestinal and oral diseases. Invasion and metastasis, both fundamental properties of malignant cancer cells, are the end result of a complex series of steps involving multiple tumor-host interactions $(17,18)$. As a result, cancer cell migration and invasion of surrounding tissues are mediated in part by MMPs, especially MMP-9 $(19,20)$.

In this study, the inhibitory effects of EGCG and its molecular mechanism on nicotine-induced MMP-9 and cell invasiveness in human ECV304 endothelial cells were examined.

\section{Materials and methods}

Cell culture and culture conditions. Human endothelial ECV304 cells obtained from the American Type Culture Collection (Manassas, VA, USA) were cultured in Dulbecco's modified Eagle's medium, supplemented with $10 \%$ fetal bovine serum (FBS) and $1 \%$ penicillin-streptomycin at $37^{\circ} \mathrm{C}$ in an atmosphere containing $5 \% \mathrm{CO}_{2}$. To determine the effects of nicotine on MMP-9 expression, cells treated with nicotine at various concentrations were harvested and the level of MMP-9 messenger RNA (mRNA), protein and promoter activity were determined. The role of EGCG (Sigma-Aldrich, St. Louis, MO, USA) in the nicotine-induced expression of MMP-9 was examined by pretreating the ECV304 cells with EGCG for $1 \mathrm{~h}$ before exposure to nicotine.

Reverse transcription-PCR. Total RNA was extracted from the ECV304 cells using TRIzol reagent (Invitrogen, Carlsbad, CA, USA). One microgram of total RNA was used for firststrand complementary DNA synthesis using random primers and the SuperScript reverse transcriptase (Invitrogen). The complementary DNA was subjected to PCR amplification with the primer sets for glyceraldehyde 3-phosphate dehydrogenase (GAPDH), MMP-9, c-fos and c-jun. The specific primer sequences were as follows: GAPDH sense, 5'-TTG TTG CCA TCA ATG ACC CC-3'; GAPDH antisense, 5'-TGA CAA AGT GGT CGT TGA GG-3' (836 bp); MMP-9 sense, 5'-AAG TGG CAC CAC CAC AAC AT-3'; MMP-9 antisense, 5'-TTT CCC ATC AGC ATT GCC GT-3' (516 bp); c-fos sense, 5'-AAC CGG AGG AGG GAG CTG ACT GAT-3'; c-fos antisense, 5'-GGG CCT GGA TGA TGC TGG GAA CA-3' (375 bp); c-jun sense, 5'-ATG GAG TCC CAG GAG CGG ATC AA-3'; and c-jun antisense, 5'-GTT TGC AAC TGC TGC GTT AG-3' (251 bp).
The PCR conditions were as follows: denaturation at $94^{\circ} \mathrm{C}$ for $30 \mathrm{sec}$, annealing at $58^{\circ} \mathrm{C}$ for $30 \mathrm{sec}$ and extension at $72^{\circ} \mathrm{C}$ for $45 \mathrm{sec}$. The products were electrophoresed in $1.5 \%$ agarose gel containing ethidium bromide.

Western blot analysis. The cells were washed in phosphatebuffered saline (PBS), detached using trypsin-EDTA buffer and stored at $-70^{\circ} \mathrm{C}$ until needed. The protein was extracted with RIPA buffer [1\% NP-40, $0.5 \%$ sodium deoxycholate, $0.1 \%$ sodium dodecyl sulfate (SDS)], protease inhibitors [aprotinin, leupeptin, phenylmethanesulfonylfluoride (PMSF), benzamidine, trypsin inhibitor and sodium orthovanadate]. Fifty micrograms of the protein was then separated by $10 \%$ SDS-PAGE and transferred to polyvinylidene fluoride membranes. The membranes were blocked in a PBS solution containing 5\% non-fat dry milk, incubated with the primary antibodies in a blocking solution overnight at $4^{\circ} \mathrm{C}$ and washed three times with TTBS $(0.1 \%$ Tween-20 in TBS) at $10-\mathrm{min}$ intervals. Horseradish peroxidase-conjugated secondary antibodies (Amersham, Arlington Heights, IL, USA) were used to detect the immunoreactive proteins by chemiluminescence. The following antibodies were used: anti-MMP-9 (R\&D Systems, Inc, Minneapolis, MN, USA) and anti-phospho-IкB (Santa Cruz Biotechnology, Santa Cruz, CA, USA). The total protein levels were assayed by washing the blotted membrane with a stripping solution composed of $100 \mathrm{mM}$ 2-mercaptoethanol, 2\% SDS and $62.5 \mathrm{mM}$ Tris- $\mathrm{HCl}(\mathrm{pH}$ 6.7) for $30 \mathrm{~min}$ at $50^{\circ} \mathrm{C}$ and the membrane was then reprobed with anti- $\beta$-actin (Sigma-Aldrich) monoclonal antibodies.

Gelatin zymography. The quantity of protein in the conditioned media was determined with a BSA protein assay kit (Pierce, USA). Subsequently, the conditioned media was mixed with an equal volume of $2 \mathrm{X}$ sample loading buffer [62.5 mM Tris- $\mathrm{HCl}$ (pH 6.8), 25\% glycerol, $4 \%$ sodium dodecyl sulfate (SDS) and $0.01 \%$ bromophenol blue; Bio-Rad, USA] and loaded onto a $7.5 \%$ acrylamide:bisacrylamide (29:1; Bio-Rad) gel containing $625 \mu \mathrm{g} / \mathrm{ml}$ gelatin (Sigma). Upon electrophoresis at $100 \mathrm{~V}$ for $2 \mathrm{~h}$, the gel was soaked in $1 \mathrm{X}$ zymogram renaturation buffer (Bio-Rad) on a rocker for $1.5 \mathrm{~h}$ at room temperature to remove residual SDS, rinsed in distilled water, incubated at $37^{\circ} \mathrm{C}$ for $18 \mathrm{~h}$ in $1 \mathrm{X}$ zymogram development buffer (Bio-Rad), stained with $0.25 \%$ (w/v) coomassie brilliant blue R-250 (Bio-Rad) and then destained in destaining buffer (10\% acetic acid and $20 \%$ methanol).

Quantitation of MMP-9. The amounts of MMP-9 in conditioned media from ECV304 cells were determined using commercially available enzyme-linked immunosorbent assay (ELISA) kits (R\&D Systems) according to the manufacturer's instructions.

Measurement of MMP-9 promoter activity. The transcriptional regulation of MMP-9 was examined by the transient transfection of an MMP-9 promoter luciferase reporter construct (pGL4-MMP-9). The plasmid pGL4-MMP-9 promoter (21) was kindly provided by Dr Young Han Lee (Konkuk University, Korea). ECV30 4 cells $\left(5 \times 10^{5}\right)$ were seeded and grown until they reached $60-70 \%$ confluence, then pRL-TK (an internal control plasmid containing the herpes simplex thymidine kinase 
promoter linked to the constitutively active Renilla luciferase reporter gene) and pGL4-MMP-9 were cotransfected into the cells using FuGene (Boehringer-Mannheim, Mannheim, Germany), according to the manufacturer's protocol. pRL-TK was transfected as an internal control. Cells were incubated in the transfection medium for $20 \mathrm{~h}$ and treated with nicotine for $5 \mathrm{~h}$. The effects of signaling inhibitors on MMP-9 promoter activity were determined by pretreating cells with EGCG for $1 \mathrm{~h}$ prior to addition of nicotine. The cotransfection studies were performed in the presence or absence of $\mathrm{NF}-\kappa \mathrm{B}$-inducting kinase (NIK), I- $\kappa \mathrm{B} \alpha$ or I- $\kappa \mathrm{B} \beta$ and AP-1 decoy oligodeoxynucleotides (ODNs). The dominant negative mutants of $\mathrm{I}-\kappa \mathrm{B} \alpha$, $\mathrm{I}-\kappa \mathrm{B} \beta$ and NIK were kindly provided by Dr D.W. Ballard (22) and Dr W.C. Greene (23), respectively. The phosphorothioate double-stranded ODNs with the sequences against the AP-1 binding site (5'-CAC TCA GAA GTC ACT TC-3' and 3'-GAA GTG ACT TCT GAG CTG-5') were prepared (Genotech, St. Louis, MO, USA) and annealed (AP-1 decoy ODNs).

Measurement of intracellular hydrogen peroxide $\left(\mathrm{H}_{2} \mathrm{O}_{2}\right)$. The level of intracellular $\mathrm{H}_{2} \mathrm{O}_{2}$ was measured using 5- and 6-carboxyl-2', 7'-dichlorodihydrofluorescein diacetate (DCFDA, Molecular Probes, Eugene, OR, USA) according to a previously-described procedure (24). Briefly, the cells were grown in serum-starved DMEM medium supplemented with $0.5 \%$ FBS for an additional 2 days. The cells were then stabilized in a serum-free DMEM medium without phenol red for $\geq 30 \mathrm{~min}$ before being exposed to nicotine for $15 \mathrm{~min}$. The effect of EGCG was assessed by pretreating the cells with EGCG for $1 \mathrm{~h}$ and incubating them with nicotine sensitive fluorophore DCFDA ( $5 \mathrm{ng} / \mathrm{ml}$ ) for $10 \mathrm{~min}$. The cells were observed immediately under a laser-scanning confocal microscope. The DCF fluorescence was excited at $488 \mathrm{~nm}$ using an argon laser and the emission evoked was filtered with a 515-nm long pass filter.

Transient transfection of $N F-\kappa B$ and $A P-1$ reporter. The $\mathrm{NF}-\kappa \mathrm{B}$ and AP-1 reporter construct was purchased from Clontech (Palo Alto, CA, USA). Once the cells had reached $60-70 \%$ confluence, they were washed with Dulbecco's modified Eagle's medium and incubated in the medium without serum and antibiotics for $18 \mathrm{~h}$. The cells were then transfected with NF- $\kappa$ B and AP-1 reporter containing the pGL3 vector using Lipofectamine 2000 (Invitrogen). Reporter transfected cells were pretreated with EGCG for $1 \mathrm{~h}$ and incubated with $200 \mu \mathrm{g} / \mathrm{ml}$ nicotine for $5 \mathrm{~h}$. The luciferase activity was measured using a luminometer.

Matrigel invasion assay. ECV304 cells $\left(5 \times 10^{4}\right)$ in $250 \mu \mathrm{l}$ of complete DMEM were seeded in the upper chamber of a 10 -well chemotaxis chamber (Neuro Probe, USA) and serum-free DMEM was placed in the lower chamber. A Matrigel-coated membrane was inserted between the two chambers. Following overnight incubation at $37^{\circ} \mathrm{C}$, the media in the upper chamber was replaced with serum-free DMEM and ECV304 cells were preincubated with the indicated concentration of EGCG and anti-MMP-9 antibody for $1 \mathrm{~h}$ and added to $200 \mu \mathrm{g} / \mathrm{ml}$ nicotine for $24 \mathrm{~h}$. Upon additional $24 \mathrm{~h}$ incubation at $37^{\circ} \mathrm{C}$ in $5 \% \mathrm{CO}_{2}$ air, the membrane was fixed and stained with a Hemacolor rapid staining kit (Merck, Germany) as per the manufacturer's instructions.
Statistics. Data are shown as the mean \pm SD and represent the mean of at least three separate experiments performed in triplicate. Differences between data sets were determined by Student's t-test. Differences described as significant in the text correspond to $\mathrm{P}<0.05$.

\section{Results}

MMP-9 expression induced by nicotine in human ECV304 endothelial cells. To determine the induction of MMP-9 expression by nicotine in human ECV304 endothelial cells, the cells were incubated with nicotine at $0-500 \mu \mathrm{g} / \mathrm{ml}$. The level of MMP-9 mRNA and protein in the cells were determined by reverse transcription-PCR and western blot analysis, respectively. As shown in Fig. 1A and B, nicotine induced MMP-9 mRNA and protein expression in a dose-dependent manner. Similarly to other members of the metalloproteinase family, MMP-9 is secreted as a pro-enzyme and then activated by proteolytic cleavage extracellularly (25). Since MMP-9 plays a pivotal role in tumor cell invasiveness, we examined the effect of nicotine on MMP-9 enzyme activities. For this goal, we performed gelatin zymography and ELISA with conditioned media harvested from nicotine-treated ECV304 cells. The gelatinolytic activity of MMP-9 was upregulated with increasing concentrations of nicotine (Fig. 1C). The level of MMP-9 was also increased by treating with nicotine determined by ELISA (Fig. 1D). Next, the effect of nicotine on transcriptional regulation of the MMP-9 gene was examined. To this end, ECV304 cells were transiently transfected with the MMP-9 promoter luciferase reporter construct (pGL4-MMP-9) and the MMP-9 promoter activity was determined. The cells treated with nicotine displayed an increase in MMP-9 promoter activity in a dose-dependent manner (Fig. 1E).

Suppressive effect of EGCG on nicotine-induced MMP-9 upregulation in human ECV304 endothelial cells. To examine the inhibitory effect of EGCG against MMP-9 enzymatic activity, ECV304 endothelial cells were subjected to RT-PCR and western blot analysis. In the presence of increased concentrations of $\operatorname{EGCG}(0,5,10,30$ and $50 \mu \mathrm{M})$ following nicotine stimulation, MMP-9 expressions were shown to be reduced in a dose-dependent manner (Fig. 2A and B). The inhibitory effects of EGCG on MMP-9 induction could also be confirmed by zymographic analysis and ELSIA assay, respectively (Fig. 2C and D). Next, we investigated whether the EGCG treatment inhibited the MMP-9 transcriptional activity induced by nicotine. As shown in Fig. 2E, cells pretreated with 10-50 $\mu \mathrm{M}$ EGCG lost most of the nicotine-induced MMP-9 transcriptional activity. EGCG at the concentrations used did not affect cell viability (data not shown).

Inhibition of nicotine-induced ROS production by EGCG. Since the ROS was known to be intracellular molecules to regulate various genes (26), we determined the role of ROS in which EGCG suppressed nicotine-induced MMP-9. The changes in the level of ROS were assayed using the $\mathrm{H}_{2} \mathrm{O}_{2}$ sensitive fluorophore DCFDA in human ECV304 endothelial cells treated with nicotine. Nicotine induced the production of ROS in the cells and pretreating the cells with 0-50 $\mu \mathrm{M}$ EGCG 
A

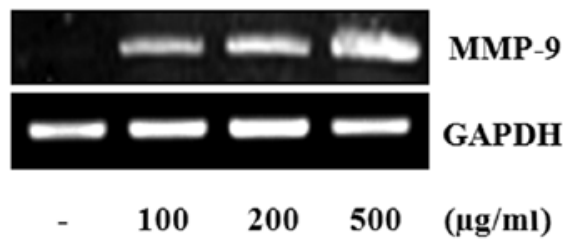

B

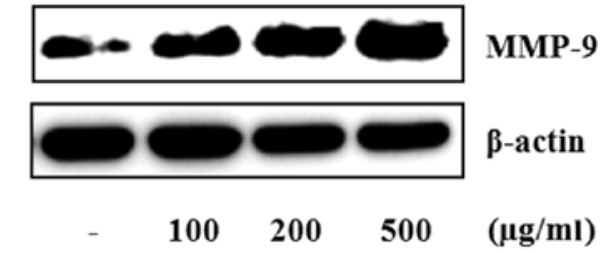

C

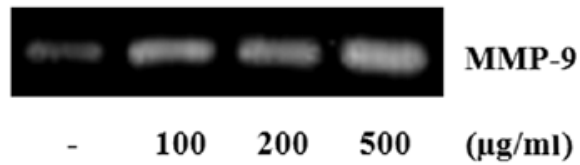

D

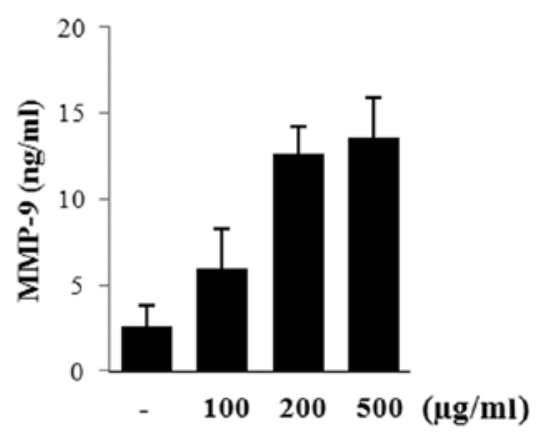

$\mathbf{E}$

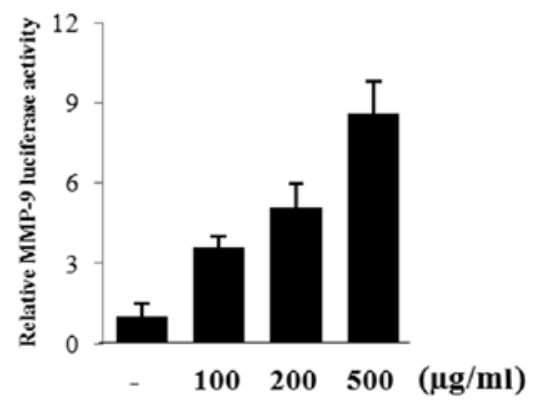

Figure 1. Effect of nicotine on the MMP-9 expression in ECV304 endothelial cells. Cells were incubated with 0-500 $\mu \mathrm{g} / \mathrm{ml}$ nicotine for $5 \mathrm{~h}$. After incubation, reverse transcription-PCR (A) and western blot (B) analyses were performed to determine the effect of nicotine on MMP-9 mRNA and protein expression in ECV304 cells. ECV304 cells treated with nicotine for $12 \mathrm{~h}$; and MMP-9 activity (C) and the MMP-9 levels (D) were determined by zymographic analysis and ELISA, respectively, in culture supernatants. (E) Cells were transiently transfected with $1 \mu \mathrm{g}$ pGL4-MMP-9 reporter construct. The transfected cells were incubated with $0-500 \mu \mathrm{g} / \mathrm{ml}$ nicotine for $5 \mathrm{~h}$ and the luciferase activity was determined using a luminometer. The data represent the mean $\pm \mathrm{SD}$ from triplicate measurements.

A

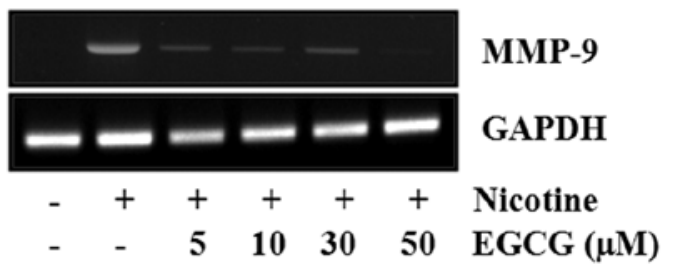

B

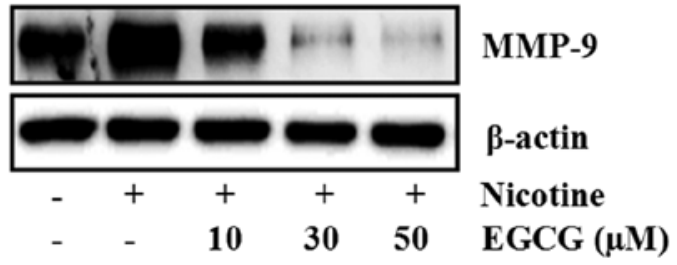

C

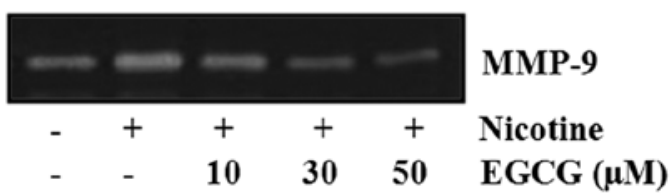

D
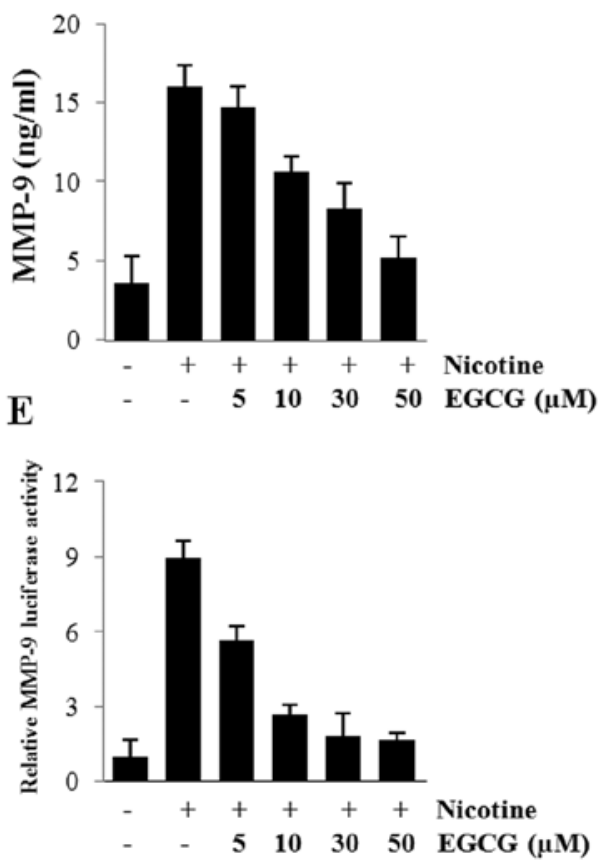

Figure 2. Effect of EGCG on nicotine-induced MMP-9 expression in ECV304 endothelial cells. ECV304 cells, after being pretreated with 0-50 $\mu$ M EGCG for $1 \mathrm{~h}$, were exposed to $200 \mu \mathrm{g} / \mathrm{ml}$ nicotine for $5 \mathrm{~h}$. After incubation, reverse transcription-PCR (A) and western blot (B) analyses were performed to determine the effect of EGCG on nicotine on MMP-9 mRNA and protein expression in ECV304 cells. ECV304 cells, pretreated with 0-50 $\mu$ M EGCG for $1 \mathrm{~h}$, were exposed to $200 \mu \mathrm{g} / \mathrm{ml}$ nicotine for $12 \mathrm{~h}$; and then MMP-9 activity (C) and the MMP-9 levels (D) were determined by zymographic analysis and ELISA, respectively, in culture supernatants. (E) Cells were transiently transfected with $1 \mu \mathrm{g}$ pGL4-MMP-9 reporter construct. The transfected cells, pretreated with 0-50 $\mu \mathrm{M}$ EGCG for $1 \mathrm{~h}$, were incubated with $200 \mu \mathrm{g} / \mathrm{ml}$ nicotine for $5 \mathrm{~h}$; and the luciferase activity was determined using a luminometer. The data represent the mean $\pm \mathrm{SD}$ from triplicate measurements. 
$\mathbf{A}$

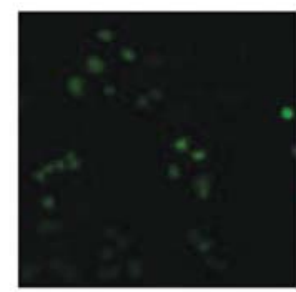

Control

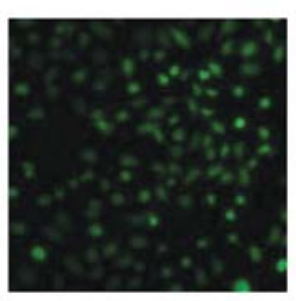

Nicotine

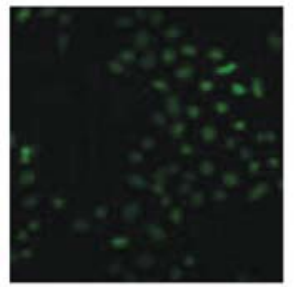

Nicotine+EGCG

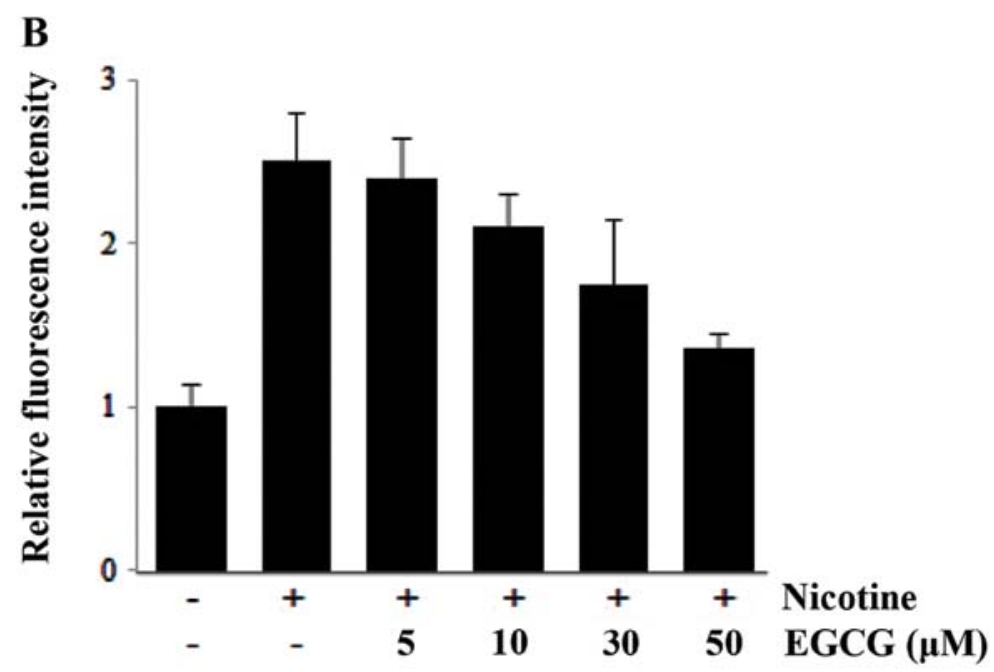

Figure 3. Effect of EGCG on nicotine-induced ROS activation in ECV304 endothelial cells. Synchronized quiescent ECV304 cells, after being pretreated with 0-50 $\mu \mathrm{M}$ EGCG for $1 \mathrm{~h}$, were incubated with nicotine $(200 \mu \mathrm{g} / \mathrm{ml})$ for $15 \mathrm{~min}$. The cells were then incubated in the dark for $10 \mathrm{~min}$ with $5 \mathrm{mg} / \mathrm{ml} \mathrm{DCFDA}$. The DCF fluorescence was imaged with a confocal laser scanning fluorescence microscope (A) and then quantified (B). The data represent the mean \pm SD from triplicate measurements.

inhibited the production of ROS in a dose-dependent manner (Fig. 3).

Effect of EGCG on the activation of transcription factor $N F-\kappa B$ during nicotine-induced MMP-9 expression. Considering that nicotine can generate ROS and that NF- $\kappa \mathrm{B}$ is a redox sensitive transcription factor $(27,28)$, the roles of $N F-\kappa B$ in the inhibitory effect of EGCG on MMP-9 expression were investigated. $\mathrm{NF}-\kappa \mathrm{B}$-dependent transcription study showed that EGCG inhibited nicotine activated NF- $\mathrm{NB}$ in a dosedependent manner (Fig. 4A). To gain further insight into the mechanism of EGCG-mediated downregulation of $\mathrm{NF}-\kappa \mathrm{B}$, the effects of EGCG on the I- $\kappa \mathrm{B}$ phosphorylation were examined. Activation of $\mathrm{NF}-\kappa \mathrm{B}$ is usually associated with the induction of $\mathrm{I}-\kappa \mathrm{B}$ phosphorylation, which is followed by its degradation by proteasome, NF- $\kappa \mathrm{B}$ nuclear translocation and subsequent activation of target gene expression. The change in the amount of I- $\kappa \mathrm{B}$ phosphorylation in ECV304 cells was determined by western blotting using an antibody to $\mathrm{I}-\kappa \mathrm{B}$ phosphorylation. As shown in Fig. 4B, EGCG inhibited the nicotine-induced phosphorylation of $\mathrm{I}-\kappa \mathrm{B}$. The involvement of $\mathrm{NF}-\kappa \mathrm{B}$ in the induction of MMP-9 by nicotine was confirmed by cotransfecting ECV304 cells with the MMP-9 promoter reporter and the dominant negative mutant forms of NF- $\mathrm{BB}$-related molecules. As shown in Fig. 4C, the expression of dominant negative mutant forms of NIK, I- $\kappa \mathrm{B} \alpha$, or I- $\kappa \mathrm{B} \beta$ resulted in a decrease of the nicotine-induced MMP-9 promoter activity.
These data indicated that NF- $\kappa \mathrm{B}$ may be a crucial molecule in the inhibitory effect of EGCG on MMP-9 expression induced by nicotine.

Role of AP-1 in EGCG-mediated MMP-9 regulation. The above results indicated that EGCG could inhibit the nicotine induced MMP-9 expression at the transcriptional level. Several tentative transcription factors, including NF- $\kappa$ B and AP-1, have been suggested to control the MMP-9 expression (29). AP-1, which consists of subunits c-fos and c-jun, is the downstream transcriptional target of Erk1/2 and JNK $(30,31)$. To determine if EGCG regulates c-fos and c-jun activation induced by nicotine, the expression of c-fos and c-jun were determined by RT-PCR. As shown in Fig. 5A, EGCG inhibited the nicotineinduced c-fos and c-jun expression in a dose-dependent manner. Furthermore, EGCG treatment caused a decrease in the AP-1-dependent transcriptional activity, as revealed by the transient transfection study using pAP-1-luciferase reporter construct (Fig. 5B). To confirm that AP-1 plays an important role in the MMP-9 expression in endothelial cells, the cells were transiently transfected with AP-1 decoy oligonucleotides and change in the MMP-9 promoter activity was examined. As shown in Fig. 5C, the MMP-9 activity was significantly decreased by AP-1 decoy transfection. The above results suggest that the transcription factor AP-1 is also involved in nicotine-induced MMP-9 expression and be a molecular target in EGCG-mediated MMP-9 regulation. 
A

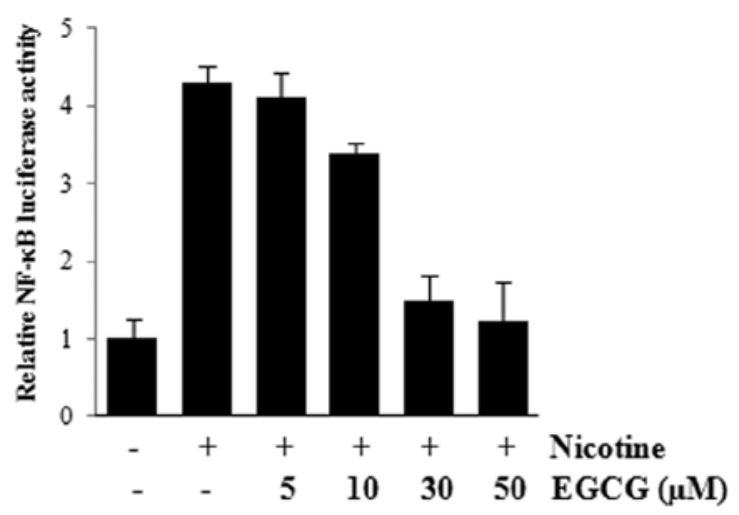

B

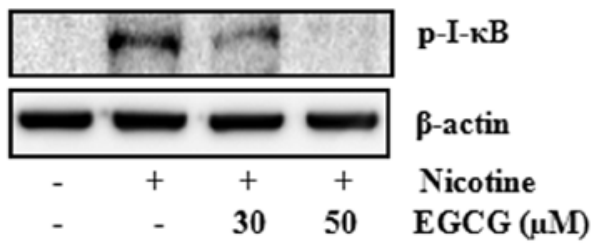

C

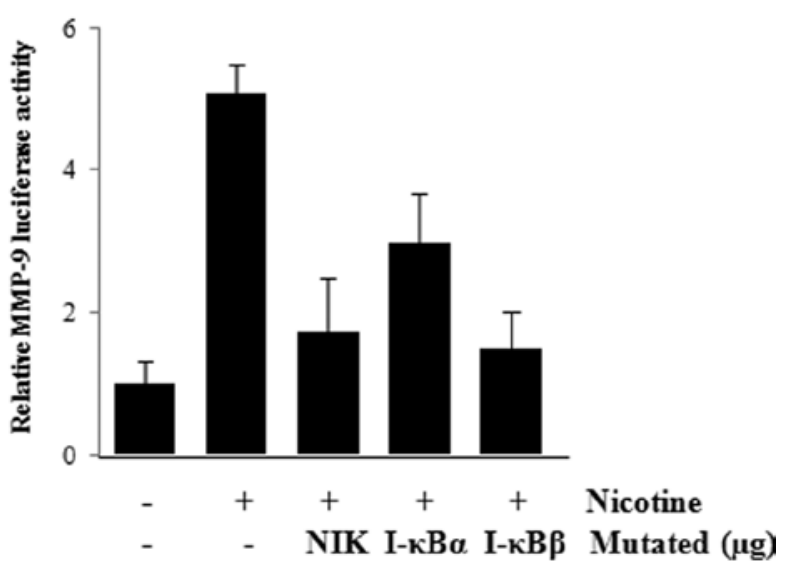

Figure 4. Effect of EGCG on nicotine-induced NF-кB activation in ECV304 endothelial cells. ECV304 cells were transiently transfected with the pNF-кB luciferase reporter construct. The transfected cells, pretreated with 0-50 $\mu \mathrm{M}$ EGCG for $1 \mathrm{~h}$, were incubated with $200 \mu \mathrm{g} / \mathrm{ml} \mathrm{nicotine}$ for $5 \mathrm{~h}$ and the luciferase activity was determined using a luminometer (A). ECV304 cells were pretreated with indicated concentrations of EGCG for $1 \mathrm{~h}$, followed by stimulation with $200 \mu \mathrm{g} / \mathrm{ml}$ nicotine for $5 \mathrm{~h}$. The levels of the phospho$\mathrm{I}-\mathrm{\kappa B}$ subunit of NF- $\mathrm{\kappa B}$ in the cell lysates were determined by western blot

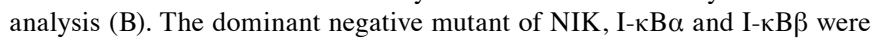
cotransfected with pGL4-MMP-9 into the ECV304. After incubation with $200 \mu \mathrm{g} / \mathrm{ml}$ nicotine for $5 \mathrm{~h}$, the luciferase activities were determined using a luminometer $(\mathrm{C})$. The data represent the mean $\pm \mathrm{SD}$ from triplicate measurements.

Effect of EGCG and anti-MMP-9 antibody on nicotineinduced cell invasion. To examine if EGCG and anti-MMP-9 antibody inhibit nicotine-induced cell invasion, modified Boyden chamber systems were employed. As shown in Fig. 6, EGCG and anti-MMP-9 antibody inhibited the invasiveness of ECV304 cells stimulated by nicotine. These results show that EGCG was able to suppress cell invasion via blocking MMP-9 expression.
A

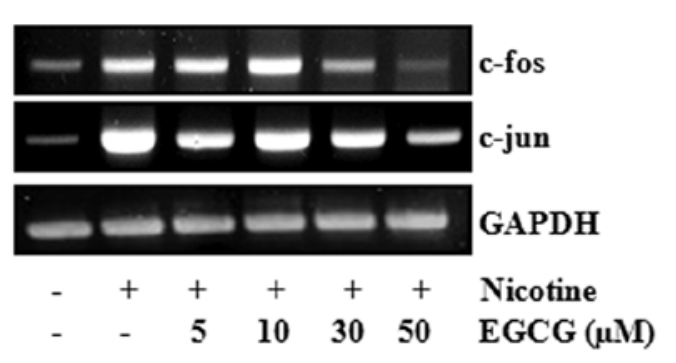

B
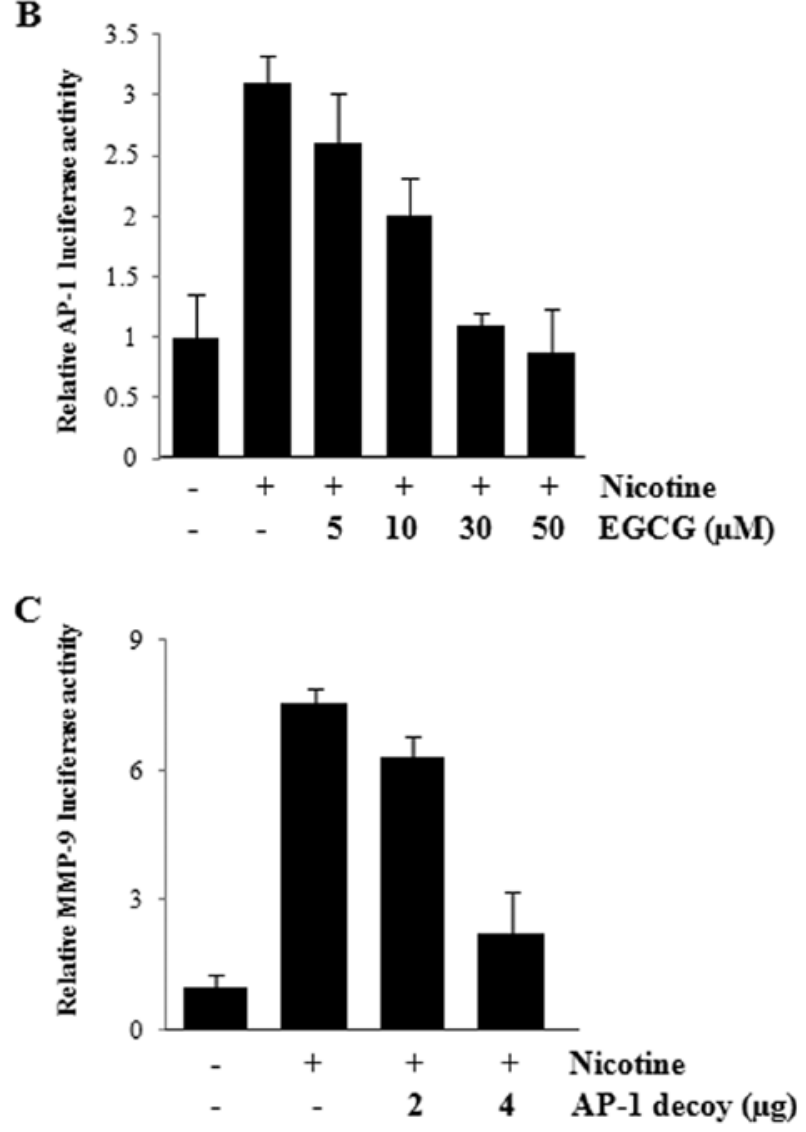

Figure 5. Effect of EGCG on nicotine-induced c-fos and c-jun expression and AP-1 activation in ECV304 endothelial cells. ECV304 cells pretreated with $0-50 \mu \mathrm{M}$ EGCG for $1 \mathrm{~h}$, were exposed to $200 \mu \mathrm{g} / \mathrm{ml}$ nicotine for $5 \mathrm{~h}$ and then reverse transcription-PCR was performed to detect the expression of c-fos and c-jun (A). ECV304 cells were transiently transfected with the pAP-1 luciferase reporter construct. The transfected cells, pretreated with $0-50 \mu \mathrm{M}$ EGCG for $1 \mathrm{~h}$, were incubated with $200 \mu \mathrm{g} / \mathrm{ml}$ nicotine for $5 \mathrm{~h}$ and the luciferase activity was determined using a luminometer (B). An AP-1 decoy oligonucleotide was cotransfected with pGL4-MMP-9 into the ECV304. After incubation with $200 \mu \mathrm{g} / \mathrm{ml}$ nicotine for $5 \mathrm{~h}$, the luciferase activities were determined using a luminometer $(C)$. The data represent the mean \pm SD from triplicate measurements.

\section{Discussion}

In endothelial cells, a potential role of the tea polyphenol (-)-epigallocatechin-3-gallate (EGCG), a major component of green tea, on nicotine-induced MMP-9 and cell invasion were investigated. To achieve our goal, we employed human ECV304 endothelial cells that had undergone spontaneous immortalization from human umbilical vein endothelial 
A

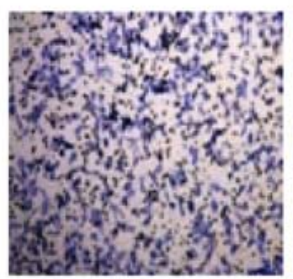

Control

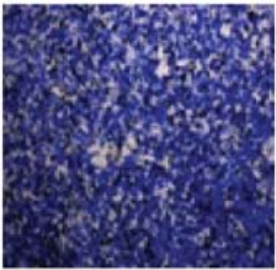

Nicotine
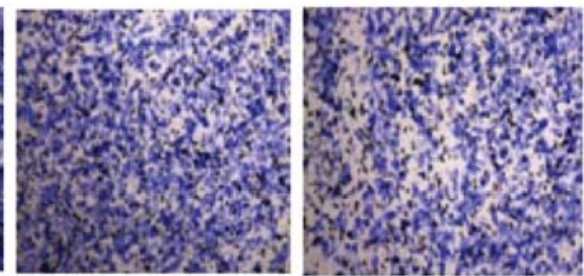

Nicotine+EGCG Nicotine+Anti-MMP-9

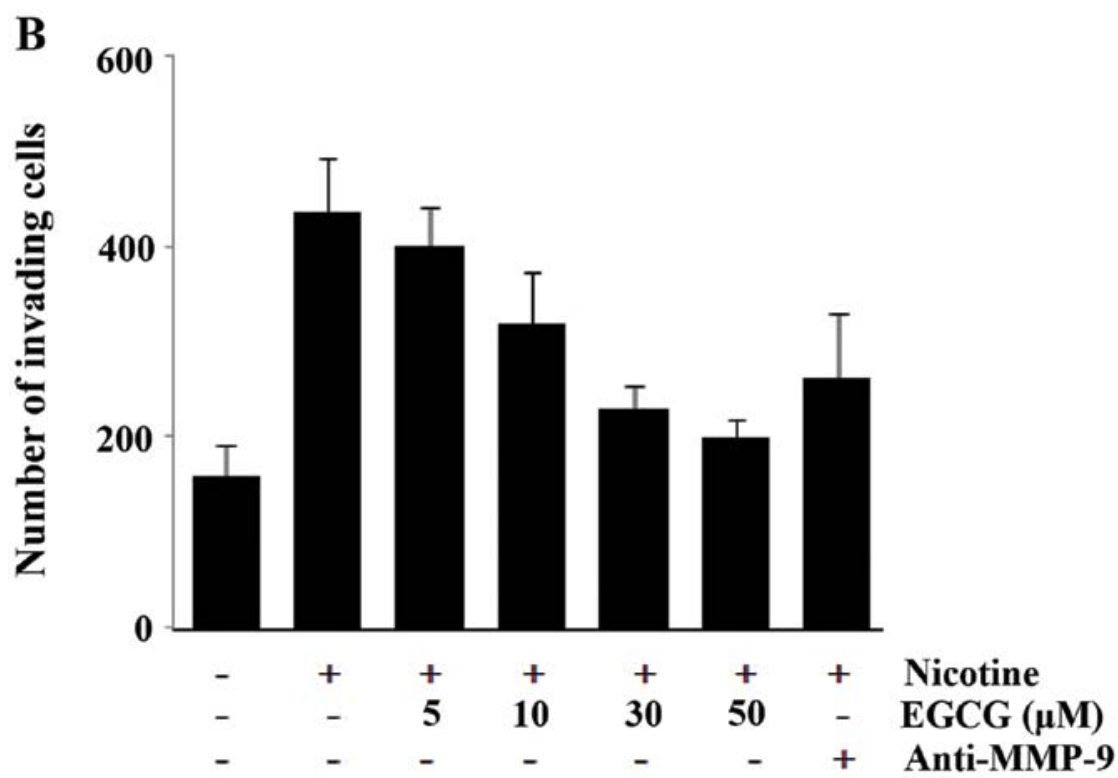

Figure 6. Effect of EGCG on nicotine-induced cell invasion in ECV304 endothelial cells. The ECV304 cells $\left(5 \times 10^{4}\right)$ were incubated with the medium for $8 \mathrm{~h}$ in the presence or absence of $50 \mu \mathrm{g} / \mathrm{ml}$ of a neutralizing antibody to MMP-9. The cells were seeded onto Matrigel coated membranes of the chamber and then pretreated with $0-50 \mu \mathrm{M}$ EGCG for $1 \mathrm{~h}$, followed by incubation with $200 \mu \mathrm{g} / \mathrm{ml}$ nicotine for additional $24 \mathrm{~h}$. The lower surfaces of the membranes from the chamber were fixed with $100 \%$ methanol and stained with a Hemacolor rapid staining kit (Merck) as per the manufacturer's instructions. Images of ECV304 cells after invasion through Matrigel coated membranes of the chamber (A). Cells that had invaded to the lower surface of the membranes were counted under a light microscope (B). The data represent the mean \pm SD from triplicate measurements.

cell (HUVEC). HUVEC has been used for many studies of endothelial cell function. However, as primary isolates, these cells exhibit a limited life span in culture and do not survive in serum-deprivation conditions used in our systems. ECV304 cells have been shown to respond to extracellular growth factors, are contact inhibited and differentiate when grown on extracellular matrix (32).

The present study suggests that EGCG inhibited nicotineinduced MMP-9 and cell invasion in ECV304 endothelial cells. Interest in green tea as a cancer chemopreventive agent in humans has intensified for several reasons (33). First, epidemiological evidence suggests that people who consume a large amount of green tea have a lower risk of various cancers. Second, green tea has been shown in animal models to protect against the development and progression of skin, lung, mammary gland and gastrointestinal tract tumors. Third, green tea extracts have been shown in vitro to stimulate apoptosis of various cancer cell lines, including prostate, lymphoma, colon and lung. Finally, green tea consumption is associated with few adverse events and it is readily available at low cost.

Nicotine alone or in combination with other substances present in the cigarette smoking is recognized as an agent for the modulation of key cellular processes involved in the pathobiological effects of tobacco (34). Nicotine has been shown to enhance cell migration, invasion and subsequent metastasis in many cancer cells (35). In addition, Jacob-Ferreira et al (36) has suggested that nicotine produces cardiovascular effects involving MMP-9. MMP-9 plays a key role in the degradation of the extracellular matrix, which is required for various pathophysiologic responses (37). Several studies have reported convincing evidence that suppression of MMPs by different inhibitors markedly reduced tumor cell invasiveness and metastasis $(38,39)$. Elevated levels and activities of MMP-9 are found in cancer tissues and tumor cells. Due to the significant role that MMPs play in cancer as well as additional human pathologies, considerable interest has focused on investigating of plant-derived compounds that can inhibit MMP activities.

Reactive oxygen species (ROS) are important messenger molecules in downstream signaling pathways and can ultimately lead to the induction of invasion-related genes including those for the MMPs (40). Our results show that nicotine stimulates the intracellular ROS production and EGCG suppress the ROS production, as determined with $\mathrm{H}_{2} \mathrm{O}_{2}$-sensitive fluorophore DCFDA. The molecular mechanism for the ROS production by nicotine remains to be elucidated. Asano et al (41) reported that nicotine activates PKC, which stimulates NADPH oxidase to generate ROS in C6 glioma cells. However, non-NADPH oxidase-dependent sources, including mitochon- 
drial electron transport, may also be importantly involved in the nicotine-induced ROS generation. EGCG has strong antioxidative capacity, high affinity for the lipid bilayers of the cell membrane and can easily enter the nuclei of cancer cells (42). EGCG is water soluble and readily oxidizable (43). Its catechol structure also makes EGCG a strong chelator of metal ions. EGCG can bind the transition metal ions, prevent formation of hydroxyl radicals and thus inhibit exogenous ROS-potentiated tumor invasion (44). Therefore, EGCG could inhibit tumor cell invasion by scavenging oxygen radicals.

This study demonstrated that the suppression of nicotineinduced MMP-9 expression by EGCG occurred at the transcriptional level as revealed by a transient transfection study using the MMP-9 promoter luciferase reporter construct. A portion of the 5'-flanking region of the MMP-9 gene has been cloned. The promoter of the MMP-9 gene contains AP-1 $(-533,-79), \mathrm{NF}-\kappa \mathrm{B}(-600)$, PEA3 (-540) and Sp1 (-558) sites for stimuli that can induce MMP-9 expression (45). EGCG inhibited the level of active NF- $\kappa \mathrm{B}$ and AP-1 induced by nicotine, indicating that $N F-\kappa B$ and AP-1 inhibition is crucial in the suppression of MMP-9 expression by EGCG in human ECV304 endothelial cells.

The following observations suggest that the inhibition of $\mathrm{NF}-\kappa \mathrm{B}$ by EGCG is involved in MMP-9 gene regulation in ECV304 cells: i) the nicotine treatment increased I- $\kappa$ B phosphorylation and $\mathrm{NF}-\kappa \mathrm{B}-\mathrm{dependent}$ transcriptional activity; ii) EGCG inhibits nicotine-induced $\mathrm{I}-\kappa \mathrm{B}$ phosphorylation and NF- $\kappa \mathrm{B}-$ dependent transcriptional activity; and iii) MMP-9 transcriptional activity was inhibited by transfection with mutated NIK, I- $\kappa \mathrm{B} \alpha$ or $\mathrm{I}-\kappa \mathrm{B} \beta$. The potent antioxidative capacity of EGCG may contribute to the prevention of $N F-\kappa B$ activation. Since the ROS was known to activate $\mathrm{NF}-\kappa \mathrm{B}$ through the phosphorylation of $\mathrm{I}-\kappa \mathrm{B}, \mathrm{EGCG}$ may prevent the ROS induction of NF- $\kappa \mathrm{B}$ activation in MMP-9 gene expression. The results that ROS production was increased within 15 min after exposing the cells to nicotine and the level of ROS were attenuated by EGCG supported the above assumption.

In the subsequent experiments, the role of AP-1 in the inhibitory effects of EGCG on nicotine-induced MMP-9 expression was also investigated. The active AP-1 complex may comprise a homodimer of c-jun or heterodimers between c-fos, c-jun and ATF2 (46). The c-jun is activated by N-terminal phosphorylation of specific serine residues (ser63/73) and it appears to be exclusively activated by JNK. The c-fos activation can be regulated by JNK and Erk signal pathways (47). Gum et al (48) suggested that regulation of MMP-9 expression in UMSCC-1 cells was regulated by JNK- and Erk-dependent signaling pathways. Simon et al (49) demonstrated that phorbol ester-enhanced MMP-9 secretion and in vitro cell invasiveness were associated with activation of p38 MAPK. In this study, EGCG suppressed nicotine-induced c-fos and c-jun expression and AP-1 activity. Since EGCG inhibited phosphorylation of receptor tyrosine kinase, it would be logical to assume that the reduction in activity of mitogen-activated protein kinase (MAPK) and AP-1 were due to the reduction in receptor activities. Previously, we showed that EGCG could directly inhibit MAPK activities in a cell-free system, although the mechanism by which EGCG inhibited the MAPK activities in the cell-free system remained to be clarified. Thus, the nicotine-induced AP-1 might be inhibited by dual effects of
EGCG in the cells: the suppression of receptor phosphorylation and direct inhibition of MAPK activities.

Our results suggest new insight into how EGCG may be involved in nicotine-induced MMP-9 expression and cell invasion in endothelial cells. Further studies are needed to elucidate the detailed mechanisms by which EGCG inhibits the MMP-9 expression and to examine whether EGCG, in fact, exerts the same effects in vivo.

\section{Acknowledgements}

This study was supported by a research grant (0720570) from the National Cancer Center, by the National Research Foundation of Korea (NRF) grant (Basic Research Program, 2010-0009910 and MRC for Gene Regulation, 2011-0030132) funded by the Korea government (MSIP).

\section{References}

1. Brunnemann KD and Hoffmann D: Analytical studies on tobacco-specific N-nitrosamines in tobacco and tobacco smoke. Crit Rev Toxicol 21: 235-240, 1991.

2. Davis R, Rizwani W, Banerjee S, Kovacs M, Haura E, Coppola D and Chellappan S: Nicotine promotes tumor growth and metastasis in mouse models of lung cancer. PLoS One 4: e7524, 2009.

3. Ji BT, Chow WH, Hsing AW, McLaughlin JK, Dai Q, Gao YT, Blot WJ and Fraumeni JF Jr: Green tea consumption and the risk of pancreatic and colorectal cancers. Int J Cancer 70: 255-258, 1997.

4. Stoner GD and Mukhtar H: Polyphenols as cancer chemopreventive agents. J Cell Biochem (Suppl) 22: 169-180, 1995.

5. Paschka AG, Butler R and Young CY: Induction of apoptosis in prostate cancer cell lines by the green tea component, (-)-epigallocatechin-3-gallate. Cancer Lett 130: 1-7, 1998.

6. Jung YD, Kim MS, Shin BA, Chay KO, Ahn BW, Liu W, Bucana CD, Gallick GE and Ellis LM: EGCG, a major component of green tea, inhibits tumour growth by inhibiting VEGF induction in human colon carcinoma cells. Br J Cancer 84: 844-850, 2001

7. Sen T, Dutta A and Chatterjee A: Epigallocatechin-3-gallate (EGCG) downregulates gelatinase-B (MMP-9) by involvement of FAK/ERK/NFkappaB and AP-1 in the human breast cancer cell line MDA-MB-231. Anticancer Drugs 21: 632-644, 2010.

8. Kim MH, Jung MA, Hwang YS, Jeong M, Kim SM, Ahn SJ, Shin BA, Ahn BW and Jung YD: Regulation of urokinase plasminogen activator by epigallocatechin-3-gallate in human fibrosarcoma cells. Eur J Pharmacol 487: 1-6, 2004.

9. Shen JZ, Zheng XF, Wei EQ and Kwan CY: Green tea catechins evoke a phasic contraction in rat aorta via $\mathrm{H}_{2} \mathrm{O}_{2}$-mediated multiple-signalling pathways. Clin Exp Pharmacol Physiol 30: 88-95, 2003.

10. Jung YD and Ellis LM: Inhibition of tumour invasion and angiogenesis by epigallocatechin gallate (EGCG), a major component of green tea. Int J Exp Pathol 82: 309-316, 2001.

11. Parsons SL, Watson SA, Brown PD, Collins HM and Steele RJ: Matrix metalloproteinases. Br J Surg 84: 160-166, 1997.

12. Chandler S, Miller KM, Clements JM, Lury J, Corkill D, Anthony DC, Adams SE and Gearing AJ: Matrix metalloproteinases, tumor necrosis factor and multiple sclerosis: an overview. J Neuroimmunol 72: 155-161, 1997.

13. Ogata Y, Pratta MA, Nagase H and Arner EC: Matrix metalloproteinase 9 (92-kDa gelatinase/type IV collagenase) is induced in rabbit articular chondrocytes by cotreatment with interleukin 1 beta and a protein kinase C activator. Exp Cell Res 201: 245-249, 1992.

14. Ma Z, Qin H and Benveniste EN: Transcriptional suppression of matrix metalloproteinase- 9 gene expression by IFN-gamma and IFN-beta: critical role of STAT-1alpha. J Immunol 167: 5150-5159, 2001.

15. Vartak DG and Gemeinhart RA: Matrix metalloproteases: underutilized targets for drug delivery. J Drug Target 15: 1-20, 2007. 
16. Konstantinopoulos PA, Karamouzis MV, Papatsoris AG and Papavassiliou AG: Matrix metalloproteinase inhibitors as anticancer agents. Int J Biochem Cell Biol 40: 1156-1168, 2008.

17. Woodhouse EC, Chuaqui RF and Liotta LA: General mechanisms of metastasis. Cancer 80: 1529-1537, 1997.

18. Mehlen P and Puisieux A: Metastasis: a question of life or death. Nat Rev Cancer 6: 449-458, 2006.

19. Arii S, Mise M, Harada T, Furutani M, Ishigami S, Niwano M, Mizumoto M, Fukumoto M and Imamura M: Overexpression of matrix metalloproteinase 9 gene in hepatocellular carcinoma with invasive potential. Hepatology 24: 316-322, 1996.

20. Klein G, Vellenga E, Fraaije MW, Kamps WA and de Bont ES: The possible role of matrix metalloproteinase (MMP)-2 and MMP-9 in cancer, e.g. acute leukemia. Crit Rev Oncol Hematol 50: 87-100, 2004.

21. Shin SY, Kim JH, Baker A, Lim Y and Lee YH: Transcription factor Egr-1 is essential for maximal matrix metalloproteinase- 9 transcription by tumor necrosis factor alpha. Mol Cancer Res 8 : $507-519,2010$

22. McKinsey TA, Brockman JA, Scherer DC, Al-Murrani SW, Green PL and Ballard DW: Inactivation of IkappaBbeta by the tax protein of human T-cell leukemia virus type 1: a potential mechanism for constitutive induction of NF-kappaB. Mol Cell Biol 16: 2083-2090, 1996

23. Geleziunas R, Ferrell S, Lin X, Mu Y, Cunningham ETJr, Grant M, Connelly MA, Hambor JE, Marcu KB and Greene WC: Human T-cell leukemia virus type 1 Tax induction of NF-kappaB involves activation of the IkappaB kinase alpha (IKKalpha) and IKKbeta cellular kinases. Mol Cell Biol 18: 5157-5165, 1998.

24. Hwang YS, Jeong M, Park JS, Kim MH, Lee DB, Shin BA, Mukaida N, Ellis LM, Kim HR, Ahn BW and Jung YD: Interleukin-1beta stimulates IL-8 expression through MAP kinase and ROS signaling in human gastric carcinoma cells. Oncogene 23: 6603-6611, 2004.

25. Mizuma M, Katayose Y, Yamamoto K, Shiraso S, Sasaki T, Yabuuchi S, Oda A, Masuda K, Rikiyama T, Onogawa T, Ohtsuka H, Motoi F, Egawa S and Unno M: Up-regulated p2 $7^{\text {Kip }}$ reduces matrix metalloproteinase-9 and inhibits invasion of human breast cancer cells. Anticancer Res 28: 2669-2677, 2008.

26. Poulsen HE, Jensen BR, Weimann A, Jensen SA, Sørensen M and Loft S: Antioxidants, DNA damage and gene expression. Free Radic Res 33: 33-39, 2000.

27. Park MJ, Lee JY, Kwak HJ, Park CM, Lee HC, Woo SH, Jin HO, Han CJ, An S, Lee SH, Chung HY, Park IC, Hong SI and Rhee CH: Arsenic trioxide $\left(\mathrm{As}_{2} \mathrm{O}_{3}\right)$ inhibits invasion of $\mathrm{HT} 1080$ human fibrosarcoma cells: role of nuclear factor-kappaB and reactive oxygen species. J Cell Bochem 95: 955-969, 2005.

28. Tobar N, Villar V and Santibanez JF: ROS-NFkappaB mediates TGF-beta1-induced expression of urokinase-type plasminogen activator, matrix metalloproteinase- 9 and cell invasion. Mol Cell Biochem 340: 195-202, 2010.

29. Kim HS, Kim MH, Jeong M, Hwang YS, Lim SH, Shin BA Ahn BW and Jung YD: EGCG blocks tumor promoter-induced MMP-9 expression via suppression of MAPK and AP-1 activation in human gastric AGS cells. Anticancer Res 24: 747-753, 2004.

30. Hipskind RA and Bilbe G: MAP kinase signaling cascades and gene expression in osteoblasts. Front Biosci 3: 804-816, 1998

31. Guedea AL, Schrick C, Guzman YF, Leaderbrand K, Jovasevic V, Corcoran KA, Tronson NC and Radulovic J: ERK-associated changes of AP-1 proteins during fear extinction. Mol Cell Neurosci 47: 137-144, 2011

32. Iwasaka $C$, Tanaka $K$, Abe $M$ and Sato $Y$ : Ets-1 regulates angiogenesis by inducing the expression of urokinase-type plasminogen activator and matrix metalloproteinase- 1 and the migration of vascular endothelial cells. J Cell Physiol 169: $522-531,1996$
33. Hong MH, Kim MH, Chang HJ, Kim NH, Shin BA, Ahn BW and Jung YD: (-)-Epigallocatechin-3-gallate inhibits monocyte chemotactic protein-1 expression in endothelial cells via blocking NF-kappaB signaling. Life Sci 80: 1957-1965, 2007.

34. Wittel UA, Momi N, Seifert G, Wiech T, Hopt UT and Batra SK: The pathobiological impact of cigarette smoke on pancreatic cancer development (Review). Int J Oncol 41: 5-14, 2012.

35. Chen RJ, Chang LW, Lin P and Wang YJ: Epigenetic effects and molecular mechanisms of tumorigenesis induced by cigarette smoke: an overview. J Oncol 2011: 654931, 2011.

36. Jacob-Ferreira AL, Palei AC, Cau SB, Moreno H Jr, Martinez ML, Izidoro-Toledo TC, Gerlach RF and Tanus-Santos JE: Evidence for the involvement of matrix metalloproteinases in the cardiovascular effects produced by nicotine. Eur J Pharmacol 627: 216-222, 2010.

37. Gialeli C, Theocharis AD and Karamanos NK: Roles of matrix metalloproteinases in cancer progression and their pharmacological targeting. FEBS J 278: 16-27, 2011.

38. Noda M, Oh J, Takahashi R, Kondo S, Kitayama $\mathrm{H}$ and Takahashi C: RECK: a novel suppressor of malignancy linking oncogenic signaling to extracellular matrix remodeling. Cancer Metastasis Rev 22: 167-175, 2003.

39. Lee HY, Park KS, Kim MK, Lee T, Ryu SH, Woo KJ, Kwon TK and Bae YS: A small compound that inhibits tumor necrosis factor-alpha-induced matrix metalloproteinase-9 upregulation. Biochem Biophys Res Commun 336: 716-722, 2005.

40. Brenneisen P, Briviba K, Wlaschek M, Wenk J and ScharffetterKochanek $\mathrm{K}$ : Hydrogen peroxide $\left(\mathrm{H}_{2} \mathrm{O}_{2}\right)$ increases the steady-state mRNA levels of collagenase/MMP-1 in human dermal fibroblasts. Free Radic Biol Med 22: 515-524, 1997.

41. Asano H, Horinouchi T, Mai Y, Sawada O, Fujii S, Nishiya T, Minami M, Katayama T, Iwanaga T, Terada K and Miwa S: Nicotine- and tar-free cigarette smoke induces cell damage through reactive oxygen species newly generated by PKC-dependent activation of NADPH oxidase. J Pharmacol Sci 118: 275-287, 2012

42. Okabe S, Suganuma M, Hayashi M, Sueoka E, Komori A and Fujiki H: Mechanisms of growth inhibition of human lung cancer cell line, PC-9, by tea polyphenols. Jpn J Cancer Res 88: 639-643, 1997.

43. Graham HN: Green tea composition, consumption and polyphenol chemistry. Prev Med 21: 334-350, 1992.

44. Zhang G, Miura Y and Yagasaki K: Suppression of adhesion and invasion of hepatoma cells in culture by tea compounds through antioxidative activity. Cancer Lett 159: 169-173, 2000

45. Sato H and Seiki M: Regulatory mechanism of $92 \mathrm{kDa}$ type IV collagenase gene expression which is associated with invasiveness of tumor cells. Oncogene 8: 395-405, 1993.

46. van Dam H and Castellazzi M: Distinct roles of Jun: Fos and Jun: ATF dimers in oncogenesis. Oncogene 20: 2453-2464, 2001.

47. Besirli CG, Wagner EF and Johnson EM Jr: The limited role of $\mathrm{NH}_{2}$-terminal c-Jun phosphorylation in neuronal apoptosis: identification of the nuclear pore complex as a potential target of the JNK pathway. J Cell Biol 170: 401-411, 2005.

48. Gum R, Wang H, Lengyel E, Juarez J and Boyd D: Regulation of $92 \mathrm{kDa}$ type IV collagenase expression by the jun aminoterminal kinase- and the extracellular signal-regulated kinase-dependent signaling cascades. Oncogene 14: 1481-1493, 1997.

49. Simon C, Simon M, Vucelic G, Hicks MJ, Plinkert PK, Koitschev A and Zenner HP: The p38 SAPK pathway regulates the expression of the MMP-9 collagenase via AP-1-dependent promoter activation. Exp Cell Res 271: 344-355, 2001 